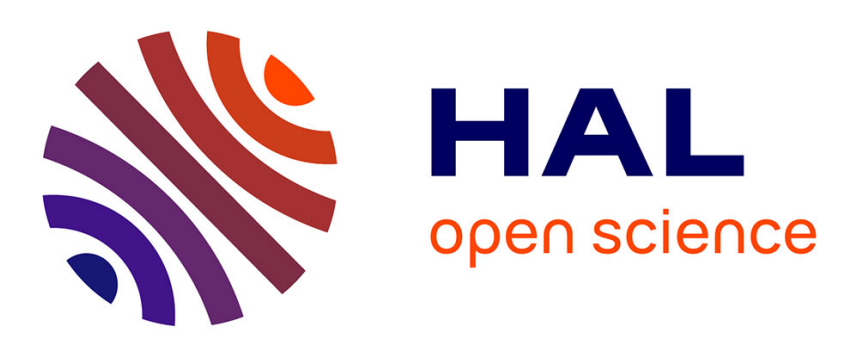

\title{
Sampling location of the inoculum is crucial in designing anodes for microbial fuel cells
}

Stephanie F. Ketep, Alain Bergel, Marie Bertrand-Huleux, Wafa Achouak, Eric Fourest

\section{> To cite this version:}

Stephanie F. Ketep, Alain Bergel, Marie Bertrand-Huleux, Wafa Achouak, Eric Fourest. Sampling location of the inoculum is crucial in designing anodes for microbial fuel cells. Biochemical Engineering Journal, 2013, vol. 73, pp. 12-16. 10.1016/j.bej.2013.01.001 . hal-00877678

\section{HAL Id: hal-00877678 \\ https://hal.science/hal-00877678}

Submitted on 29 Oct 2013

HAL is a multi-disciplinary open access archive for the deposit and dissemination of scientific research documents, whether they are published or not. The documents may come from teaching and research institutions in France or abroad, or from public or private research centers.
L'archive ouverte pluridisciplinaire HAL, est destinée au dépôt et à la diffusion de documents scientifiques de niveau recherche, publiés ou non, émanant des établissements d'enseignement et de recherche français ou étrangers, des laboratoires publics ou privés. 


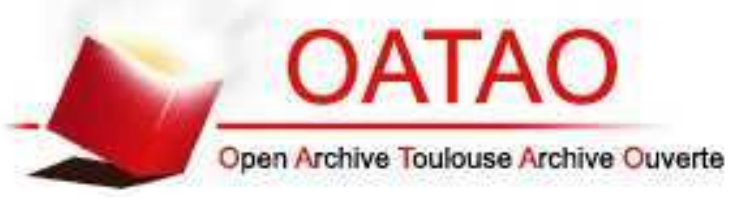

\section{Open Archive TOULOUSE Archive Ouverte (OATAO)}

OATAO is an open access repository that collects the work of Toulouse researchers and makes it freely available over the web where possible.

This is an author-deposited version published in : http://oatao.univ-toulouse.fr/ Eprints ID : 9930

To link to this article : DOI:10.1016/j.bej.2013.01.001

URL : http://dx.doi.org/10.1016/j.bej.2013.01.001

To cite this version : Ketep, Stephanie F. and Bergel, Alain and Bertrand, Marie and Achouak, Wafa and Fourest, Eric. Sampling location of the inoculum is crucial in designing anodes for microbial fuel cells. (2013) Biochemical Engineering Journal, vol. 73 . pp. 12-16. ISSN 1369$703 \mathrm{X}$

Any correspondance concerning this service should be sent to the repository administrator: staff-oatao@ listes-diff.inp-toulouse.fr 


\title{
Sampling location of the inoculum is crucial in designing anodes for microbial fuel cells
}

\author{
Stephanie F. Ketep ${ }^{\mathrm{a}, \mathrm{b}, *}$, Alain Bergel ${ }^{\mathrm{b}}$, Marie Bertrand ${ }^{\mathrm{c}}$, Wafa Achouak $^{\mathrm{c}}$, Eric Fourest ${ }^{\mathrm{a}}$ \\ a Centre Technique du Papier, BP 251, 38044 Grenoble Cedex 9, France \\ b Laboratoire de Génie Chimique (LGC), CNRS-Université de Toulouse (INPT), BP 84234, 31432 Toulouse, France \\ ${ }^{\mathrm{c}}$ Laboratoire d'Ecologie Microbienne de la Rhizosphère et d'Environnements Extrêmes (LEMiRE), UMR 6191, CNRS-CEA-Aix-Marseille Université, CEA/DSV/iBEB, CEA Cadarache, 13108 \\ Saint Paul Lez Durance, France
}

Keywords:

Microbial fuel cell (MFC)

Waste-water treatment

Pulp mill effluent

Bioanode

Inoculum

\begin{abstract}
A B S T R A C T
A Kraft pulp mill effluent was used as the inoculum to form microbial bioanodes under controlled potential at $+0.4 \mathrm{~V} / \mathrm{SCE}$. Samples were collected at the inlet and outlet of the aerated lagoon of the treatment line. The outlet sample allowed efficient bioanodes to be designed $\left(5.1 \mathrm{~A} / \mathrm{m}^{2}\right)$, which included Geobacter and Desulfuromonas sp. in their microbial community. In contrast, the bioanodes formed with the inlet sample did not contain directly connecting anode-respiring bacteria and led to lower currents. It was necessary to re-form this bioanode at lower applied potential $(-0.2 \mathrm{~V} / \mathrm{SCE})$ to select more efficient electroactive species and increase the current density to $5 \mathrm{~A} / \mathrm{m}^{2}$.
\end{abstract}

\section{Introduction}

Microbial fuel cells (MFCs) are presented as a promising technology for the treatment of various wastewaters with concomitant generation of electrical current [1]. It can be suspected that the capacity of an effluent to form efficient microbial anodes may vary depending on the location along the processing line. For instance, a recent article has demonstrated very different MFC performance levels depending on the sites where samples were taken from the same freshwater lake [2]. Nevertheless, this question has rarely been addressed up to now in the framework of wastewater treatment [3] even though it appears to be essential to determine the best implantation of an MFC in a wastewater treatment line.

The purpose of this work was to assess the suitability of an effluent to form microbial anodes depending on whether it was positioned at the entrance or at the outlet of an aerated lagoon. An effluent from a Kraft pulp mill was chosen because of the great interest of the pulp and paper industries in finding new equipment to treat their effluents. The effluent samples were mixed with a synthetic medium that contained only small amounts of ammonium and phosphate. Such nutrients are commonly added at industrial scale to enhance the treatment of pulp and paper mill effluents

\footnotetext{
* Corresponding author at: Laboratoire de Génie Chimique (LGC) CNRS-Université de Toulouse (INPT), BP 84234,31234 Toulouse, France. Tel.: +33 534323673.

E-mail address: francoise.ketep@ensiacet.fr (S.F. Ketep).
}

that present nutriment deficiencies. Here, the concentrations of the added compounds were minimal to prevent excessive enrichment and, particularly, an artificial buffering effect. Acetate was added to the effluent to stabilize the experimental conditions. Acetate is commonly present in these effluents as it is provided by the hydrolysis and acidogenesis of polysaccharides. Using such operating conditions, we expected to check the effluent samples under conditions not too far from those that can be found in an actual treatment process.

Bioanodes were formed under constant polarization at $+0.4 \mathrm{~V} / \mathrm{SCE}$. Such a high value has been found to be optimal for forming microbial anodes from a wild source of inoculum [4]. In marine sediments [5], microbial anodes formed at a high polarization potential of $0.618 \mathrm{~V}$ (vs. $\mathrm{Ag} / \mathrm{AgCl}$ ) have produced higher currents than those formed at lower potential $(-0.058 \mathrm{~V}$ vs. $\mathrm{Ag} / \mathrm{AgCl})$. We postulated that, as already observed by Torres et al. [6], high potential would result in larger biodiversity of the microbial communities growing on the anode surface, giving the best chance of catching and growing suitable anode respiring bacteria (ARB).

\section{Materials and methods}

\subsection{Electrochemical experiments}

Reactors were closed glass cells containing $450 \mathrm{~mL}$ of solution. Working electrodes were flat $10 \mathrm{~cm}^{2}$ graphite plates (Goodfellow) with smooth surfaces. $10 \mathrm{~cm}^{2}$ platinum-iridium grids (Heraeus) 
were used as auxiliary electrodes and a saturated calomel electrode (SCE, Radiometer) was used as the reference (potential $+0.24 \mathrm{~V} / \mathrm{SHE}$ ). Reactors were maintained at $25^{\circ} \mathrm{C}$. Inocula came from an aerated lagoon that treated the wastewater of a Kraft pulp mill. Samples were collected from the inlet (raw effluent, average COD $945 \mathrm{mg} / \mathrm{L}$ ) and the outlet (effluent after treatment, average COD $432 \mathrm{mg} / \mathrm{L}$ ) of the lagoon.

The reactors were filled with $250 \mathrm{~mL}$ of effluent sample mixed with $200 \mathrm{~mL}$ of synthetic medium $\left(23.8 \mathrm{mM} \mathrm{NaHCO}_{3}, 28 \mathrm{mM} \mathrm{NH}_{4} \mathrm{Cl}\right.$, $5 \mathrm{mM} \mathrm{NaH}_{2} \mathrm{PO}_{4}, 10 \mathrm{mM} \mathrm{KCl}, 5 \mathrm{mM}$ sodium acetate, $\mathrm{pH}$ adjusted to 7.0 with $\mathrm{HCl} 1 \mathrm{M}$ ). The solutions were sparged with nitrogen for $10 \mathrm{~min}$ at the beginning of each experiment. Primary bioanodes were formed under constant potential of $+0.4 \mathrm{~V} / \mathrm{SCE}$. Two reactors were run in parallel, each containing a different effluent sample (inlet or outlet) and using a multi-channel potentiostat (BioLogic SA). Current densities were expressed with respect to the anode surface area. Sodium acetate $(5 \mathrm{mM})$ was added when the current decreased to zero. Cyclic voltammetry (CV) curves were recorded at the end of each chronoamperometry and always involved three successive scans $(10 \mathrm{mV} / \mathrm{s})$. The second and third scans were perfectly reproducible and only the second scans are reported here. Secondary and tertiary bioanodes were formed by re-inoculating the primary and secondary bioanodes respectively. The biofilms were detached from the graphite electrode by ultrasonication in $30 \mathrm{~mL}$ physiological Ringer solution. Fresh reactors containing $200 \mathrm{~mL}$ of synthetic medium and $250 \mathrm{~mL}$ of effluent were inoculated with $5 \mathrm{~mL}$ of the primary or secondary biofilms. The $250 \mathrm{~mL}$ of effluent was previously filtered at $0.2 \mu \mathrm{m}$ to remove planktonic bacteria. Secondary bioanodes were formed at $+0.4 \mathrm{~V} / \mathrm{SCE}$ and tertiary bioanodes in the range of -0.2 to $-0.4 \mathrm{~V} / \mathrm{SCE}$.

\subsection{Analysis of the microbial communities by denaturing gradient gel electrophoresis (DGGE)}

Each biofilm was vigorously scraped from the electrode surface with a sterile glass spreader in sterile medium (M9). Bacterial communities were targeted by amplification of $16 \mathrm{~S}$ using a pair of universal primers (fd1 and rd1) corresponding to positions $8 \pm 27$ and $1524 \pm 1540$. The resulting PCR fragment was amplified by a nested PCR approach using primers 329f-GC and 919r generating $590 \mathrm{bp}$ fragments [7]. DGGE was implemented with a first PCR amplification followed by nested amplification using primers yielding shorter sequences ( $590 \mathrm{bp}$ ). The nested PCR allowed a significant amount of DNA to be produced from any member of the community that had a target gene. The PCR-amplified DNA was separated on an electrophoresis gel with a gradient of DNA denaturant (urea + formamide). Certain bands were excised for new amplifications by PCR and identification by subsequent sequencing [7].

\section{Results and discussion}

\subsection{Formation of primary, secondary and tertiary bioanodes} under chronoamperometry $(C A)$

The lagoon inlet and outlet samples mixed with minimal synthetic medium were used in two parallel reactors to form bioanodes under polarization at $+0.4 \mathrm{~V} / \mathrm{SCE}$ (Fig. $1 \mathrm{~A}$ ). Current peaks were obtained for each successive addition of $5 \mathrm{mM}$ acetate. The maximum current densities were more than three times as high with outlet sample $\left(2.2 \mathrm{~A} / \mathrm{m}^{2}\right.$ at day 18$)$ than with inlet sample $\left(0.6 \mathrm{~A} / \mathrm{m}^{2}\right.$ at day 19).

Primary biofilms were scraped from the electrodes and used as inocula in new reactors (Fig. 1B). Both secondary bioanodes gave improved electrochemical performance; the maximum current densities increased to $1.6 \mathrm{~A} / \mathrm{m}^{2}$ (inlet) and $5.1 \mathrm{~A} / \mathrm{m}^{2}$ (outlet).
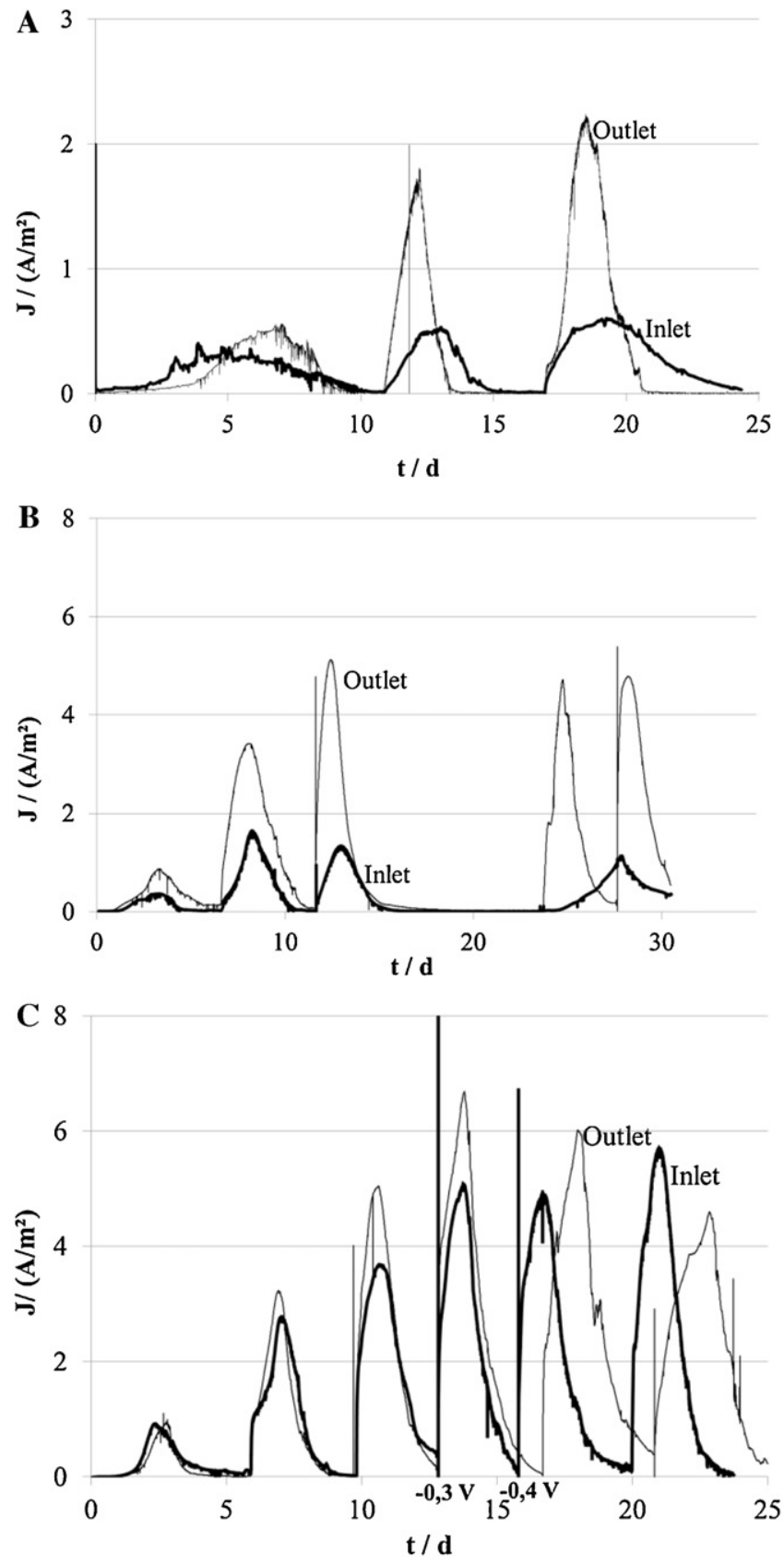

Fig. 1. Current density versus time for EA biofilms formed from the lagoon inlet and outlet samples with smooth graphite electrodes under different applied potentials. (A) Primary biofilms at $+0.4 \mathrm{~V} / \mathrm{SCE}$, (B) secondary biofilms at $+0.4 \mathrm{~V} / \mathrm{SCE}$ and (C) tertiary biofilms with applied potential between $-0.2 \mathrm{~V}$ and $-0.4 \mathrm{~V} / \mathrm{SCE}$. Potential values on the $X$-axis represent changes during experiments.

Increased performance obtained by inoculating with an alreadyelectroactive biofilm has often been reported in the literature $[8,9]$. Similarly to the primary bioanodes, the secondary bioanodes coming from the outlet sample led to currents around 3-fold those of the inlet sample.

Torres et al. [10] have postulated that bioanodes formed at high potential contain non-electroactive bacteria that form a poorly conductive layer and hinder the development of directly connecting anode respiring bacteria (ARB). To avoid this possible effect, it was chosen to disrupt the secondary biofilms here, in order to investigate the effect of lowering the potential on the formation of tertiary bioanodes (Fig. 1C). The effect of the lower potential $(-0.2 \mathrm{~V} / \mathrm{SCE})$ was drastically different depending on the inoculum. 

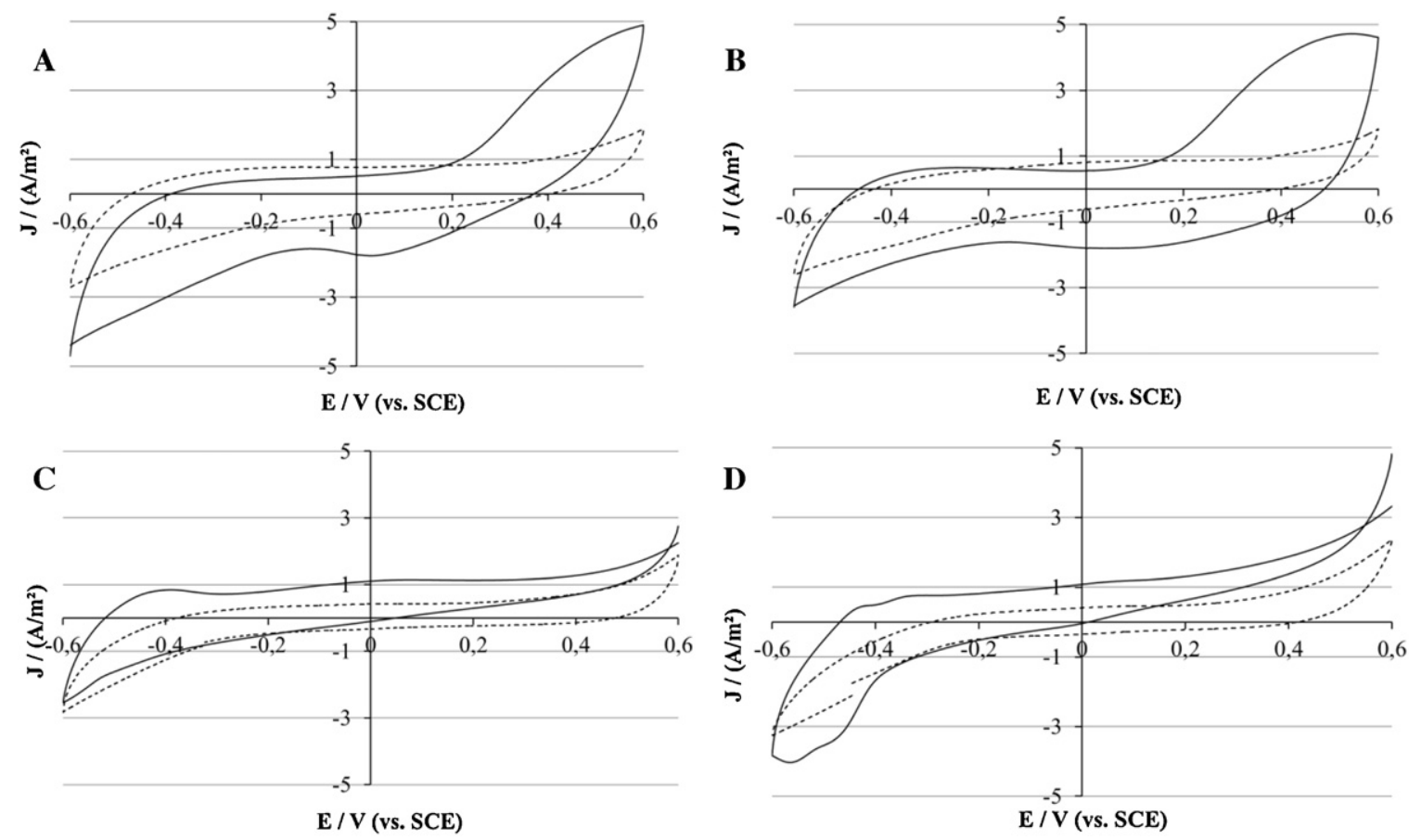

Fig. 2. Cyclic voltammetry $(10 \mathrm{mV} / \mathrm{s})$ recorded at the end of chronoamperometries. (-) Clean electrode, ( - ) colonized electrode. (A) Primary biofilms from lagoon inlet, day 25 of Fig. 1A; (B) primary biofilms from lagoon outlet, day 25 of Fig. 1A; (C) tertiary biofilms from lagoon inlet, day 25 of Fig. 1C; (D) tertiary biofilms from lagoon outlet, day 25 of Fig. $1 C$.

For the outlet inoculum, the tertiary bioanode showed current density similar to the secondary one. In contrast, the inlet inoculum led to current improved by a factor of 3 with respect to the secondary bioanode. On day 12 , the potential of the two electrodes was changed to $-0.3 \mathrm{~V} / \mathrm{SCE}$ and the performance increased slightly for both bioanodes. Finally, performance remained unchanged at $-0.4 \mathrm{~V} / \mathrm{SCE}$ (from day 16 ).

\subsection{Analysis of microbial communities of primary bioanodes by $C V$ and DGGE}

The primary bioanodes were characterized by cyclic voltammetry (CV) at the end of CA (day 25). Each CV showed a clear oxidation wave starting from around $0.2 \mathrm{~V} / \mathrm{SCE}$. The control CVs recorded with a clean electrode introduced into each reactor did not detect any faradic current (Fig. 2A and B). The oxidation waves were not related to acetate oxidation because no current was provided at $+0.4 \mathrm{~V} / \mathrm{SCE}$ during the CA just before recording CV (Fig. 1). These waves corresponded to the oxidation of redox compounds contained in the biofilm, which were reduced during the backward scan, as shown by the currents observed on the reduction scans.

High bacterial diversity was observed on the primary biofilms (Fig. 3A). Several microbial genera, such as Clostridium, Desulfuromonas, Pseudomonas and Geobacter, have already been described as ARB [7], while others, such as Hydrogenophaga, Dechloromonas, Fluvicola, Fusibacter, Aquimonas, Flavobacter or Cryomorphaceae have not yet been described as electroactive. It has been reported that forming biofilms at high potential results in greater microbial diversity, while lower potentials select the most efficient ARB $[10,11]$ that achieve electron transfer by direct contact with the electrode surface or through a conductive matrix. Geobacter [12,13] and Desulfuromonas sp. [14] belong to such directly connecting ARB. In contrast, biofilms formed at high potentials are believed to predominantly contain ARB that produce electron shuttles, such as Pseudomonas and Clostridium [15] and possibly non-electroactive species. Here, both the inlet and outlet samples confirmed a microbial diversity including ARB and nonelectroactive species.

The high microbial diversity observed by DGGE was consistent with the absence of well-defined redox phenomena in the CVs. The oxidation wave at high potentials may be due to several redox compounds entrapped in the biofilm. Both biofilms contained Clostridium sp. known to produce extracellular redox mediators. On the other hand, the higher Geobacter and Desulfuromonas content of the bioanode that resulted from the outlet inoculum was consistent with the higher current densities provided.

\subsection{Analysis of microbial communities of tertiary bioanodes by $C V$ and $D G G E$}

The microbial composition of the tertiary anodes showed a few predominant bacterial species (Fig. 3B). Geobacter metallireducens, Pelobacter propionicus and Desulfuromonas acetexigens were identified in the biofilm from the outlet sample, while only $D$. acetexigens was identified in the biofilm from the inlet sample. Pelobacter species seem not to be electroactive [16] but have often been detected in wild electroactive biofilms $[17,18]$. D. acetexigens has also been recently found to be the sole predominant species of wild electroactive biofilms [19], as was the case here in the biofilm formed from the inlet sample. The nested DGGE procedure used here allowed even poorly represented bacterial populations to be accessed. It can consequently be concluded that $D$. acetexigens was strongly dominant in the tertiary biofilm coming from the inlet sample.

CVs recorded at the end of CA fitted the DGGE analyses well (Fig. 2C and D). Two redox systems were observed with the bioanode formed from outlet inoculum (mid-potentials around -0.40 and $-0.50 \mathrm{~V} / \mathrm{SCE}$ ), which may correspond to the two species G. metallireducens and $D$. acetexigens. The inlet biofilm only exhibited one, strongly defined redox system (around $-0.45 \mathrm{~V} / \mathrm{SCE}$ ), consistently with the sole predominant species $D$. acetexigens detected by DGGE. 

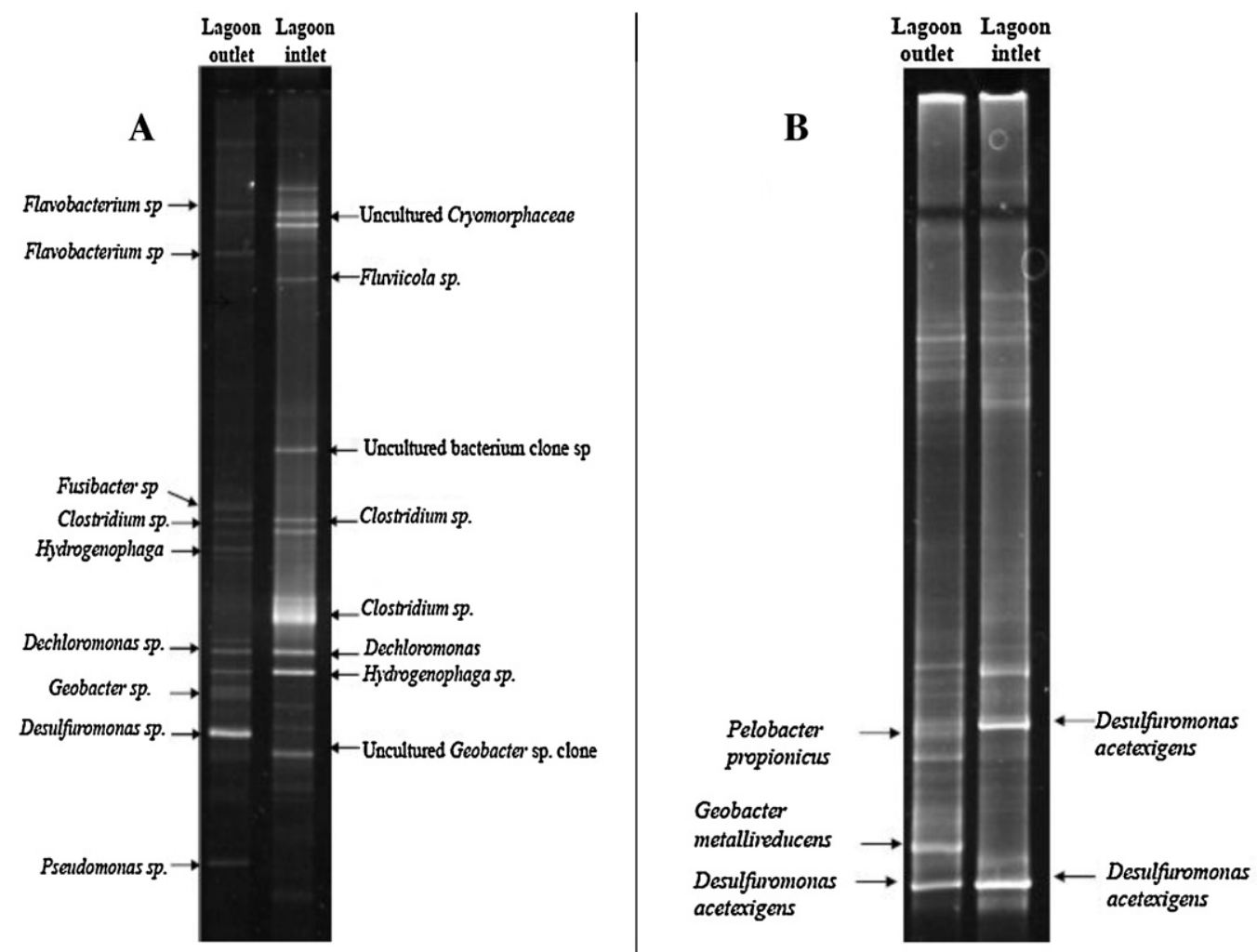

Fig. 3. DGGE profiles of the biofilm grown on graphite electrodes from lagoon inlet and lagoon outlet samples. (A) Primary biofilms (end of Fig. 1A); (B) tertiary biofilms (end of Fig. 1C).

\section{Conclusions}

The outlet inoculum led to efficient bioanodes from the first inoculation at $+0.4 \mathrm{~V} / \mathrm{SCE}\left(2.2 \mathrm{~A} / \mathrm{m}^{2}\right)$. Re-inoculation increased the current to $5.1 \mathrm{~A} / \mathrm{m}^{2}$. Lowering the potential (tertiary bioanode) did not increase the current because the microbial population of the primary bioanode was effective enough and stronger selection at lower potential was not necessary.

In contrast, the inlet sample led to smaller currents at $+0.4 \mathrm{~V} / \mathrm{SCE}$. Lowering the potential to $-0.2 \mathrm{~V} / \mathrm{SCE}$ increased the current density significantly because the primary biofilm did not contain the directly connecting ARB and the lower potential was required to select more efficient electroactive species.

To the best of our knowledge, this is the first time that such differences have been evidenced by using different sampling locations of the same effluent. Using a minimal synthetic medium that did not mask the intrinsic properties of the inocula was certainly a suitable way to compare the capabilities of various samples to form microbial anodes.

\section{Acknowledgments}

This work was done in the framework of the "Agri-Elec (ANR008-BioE-001)" project, which is supported by the French National Research Agency (ANR).

\section{References}

[1] B.E. Logan, K. Rabaey, Conversion of wastes into bioelectricity and chemicals by using microbial electrochemical technologies, Science 337 (2012) 686-690.

[2] T. Song, H. Cai, Z. Yan, Z. Zhao, H. Jiang, Various voltage productions by microbial fuel cells with sedimentary inocula taken from different sites in one freshwater lake, Bioresour. Technol. 108 (2012) 68-75.
[3] D. Jiang, B. Li, W. Jia, Y. Lei, Effect of inoculum types on bacterial adhesion and power production in microbial fuel cells, Appl. Biochem. Biotechnol. $160(2010)$ 182-196.

[4] S. Parot, M. Délia, A. Bergel, Forming electrochemically active biofilms from garden compost under chronoamperometry, Bioresour. Technol. 99 (2008) $4809-4816$

[5] L.M. Tender, J.G. Zeikus, D.A. Finkelstein, Effect of electrode potential on electrode-reducing microbiota, Environ. Sci. Technol. 40 (2006) 6990-6995.

[6] C.I. Torres, A.K. Marcus, B.E. Rittmann, Kinetics of consumption of fermentation products by anode respiring bacteria, Appl. Microbiol. Biotechnol. 77 (2007) 689-697.

[7] F.EZ Haichar, C. Marol, O. Berge, JI. Rangel-Castro, JI. Prosser, J. Balesdent, T. Heulin, W. Achouak, Plant host habitat and root exudates shape soil bacterial community structure, ISME J. 2 (2008) 1221-1230.

[8] K. Rabaey, N. Boon, S.D. Siciliano, M. Verhaege, W. Verstraete, Biofuel cells select for microbial consortia that self-mediate electron transfer, Appl. Environ. Microbiol. 70 (2004) 5376-5382.

[9] A. Wang, D. Sun, N. Ren, C. Liu, W. Liu, B. Logan, W. Wu, A rapid selection strategy for an anodophilic consortium for microbial fuel cells, Bioresour. Technol. 101 (2010) 5733-5735.

[10] C.I. Torres, R. Krajmalnik-Brown, P. Parameswaran, A.K. Marcus, G. Wanger, Y.A. Gorby, B.E. Rittmann, Selecting anode-respiring bacteria based on anode potential: phylogenetic, electrochemical, and microscopic characterization, Environ. Sci. Technol. 43 (2009) 9519-9524

[11] P. Aelterman, S. Freguia, J. Keller, W. Verstraete, K. Rabaey, The anode potential regulates bacterial activity in microbial fuel cells, Appl. Microbiol. Biotechnol. 78 (2008) 409-418.

[12] H. Richter, K.P. Nevin, H. Jia, D.A. Lowy, D.R. Lovley, L.M. Tender, Cyclic voltammetry of biofilms of wild type and mutant Geobacter sulfurreducens on fuel cell anodes indicates possible roles of $O m c B, O m c Z$, type IV pili, and protons in extracellular electron transfer, Environ. Sci. Technol. 2 (2009) 506-516.

[13] K.P. Nevin, B. Kim, R.H. Glaven, J.P. Johnson, T.L. Woodard, B.A. Methé, R.J. DiDonato Jr., S.F. Covalla, A.E. Franks, A. Liu, D.R. Lovley, Anode biofilm transcriptomics reveals outer surface components essential for high density current production in Geobacter sulfurreducens fuel cells, PLoS ONE 4 (2009) e5628.

[14] S. Alves, C.M. Paquete, B.M. Fonseca, R.O. Louro, Exploration of the 'cytochromome' of Desulfuromonas acetoxidans, a marine bacterium capable of powering microbial fuel cells, Metallomics 3 (2011) 349-353.

[15] A.E. Franks, K.P. Nevin, Microbial fuel cells, a current review, Energies 3 (2010) 899-919.

[16] H. Richter, M. Lanthier, K.P. Nevin, D.R. Lovley, Lack of electricity production by Pelobacter carbinolicus indicates that the capacity for Fe(III) oxide reduction 
does not necessarily confer electron transfer ability to fuel cell anodes, Appl. Environ. Microbiol. 73 (2007) 5347-5353.

[17] S. Freguia, E.H. Teh, N. Boon, K.M. Leung, J. Keller, K. Rabaey, Microbial fuel cells operating on mixed fatty acids, Bioresour. Technol. 101 (2010) 1233-1238.

[18] P. Parameswaran, H. Zhang, C.I. Torres, B.E. Rittmann, R. Krajmalnik-Brown Microbial community structure in a biofilm anode fed with a fermentable substrate: the significance of hydrogen scavengers, Biotechnol. Bioeng. 105 (2010) 69-78.

[19] S.F. Ketep, A. Bergel, M. Bertrand, W. Achouak, E. Fourest, Lowering the applied potential during successive scratching/re-inoculation improves the performance of microbial anodes for microbial fuel cells, Bioresour. Technol. 127 (2013) 448-455. 